This is an Open Access article, distributed under the terms of the Creative Commons Attribution licence (http://creativecommons.org/licenses/by/3.o/), which permits unrestricted re-use, distribution, and reproduction in any medium, provided the original work is properly cited.

doi:10.1017/So144686X15000197

\title{
No children in later life, but more and better friends? Substitution mechanisms in the personal and support networks of parents and the childless in Germany
}

\author{
SEBASTIAN SCHNETTLER* and THOMAS WÖHLER*
}

\begin{abstract}
Given increases in childlessness, we ask if and how the permanently childless substitute for adult children in their later-life support networks. Previous research finds that they are disadvantaged on several network and support indicators. Yet, the role of different substitution mechanisms remains unclear. We examine two substitution mechanisms: substitution through adjustments of network size/composition and through higher efficiency of personal ties. Data are from the German Ageing Survey (childless: $\mathrm{N}=1,886$; parents without/with residentially proximate children: $\mathrm{N}=4,437 / 8,337)$. Our descriptive and regression results on network size/composition and the number of potential informational and emotional supporters show that both mechanisms play a role: the childless have more friends and extended kin, and they are more likely to consider them as potential supporters, than parents. Across cohorts or age groups, the relative effect size of network size/composition versus tie efficiency changes. Parents with no children nearby constitute a mixed type that shows similarities to the childless on some indicators of social support and to parents with at least one child nearby on other indicators. Our findings provide a foundation for better predicting how current demographic trends affect future scenarios of social support in later life and for identifying the future need for formal care services. Thus, they are relevant for social scientists and policy makers alike.
\end{abstract}

KEY WORDS - ageing, childlessness, friendship, kinship, social networks, social support, parenthood.

\section{Introduction}

Adult children play an important role as supporters for parents in later life, particularly for those without a partner or spouse (Lye 1996; Rossi and

* Department of Sociology, University of Konstanz, Germany. 


\section{Sebastian Schnettler and Thomas Wöhler}

Rossi 1990; Schnettler 2008; Silverstein, Bengtson and Lawton 1997; Szydlik 1995). This finding is consistent across countries with different welfare regimes (for a summary, see Wenger et al. 2007). On average, parents in later life and their adult children, as well as grandparents and their grandchildren, seem to be well engaged in mutual intergenerational exchange (e.g. Fergusson, Maughan and Golding 2008; Hoff 2007; Kohli and Künemund 2000). The bonds between grandparents and their grandchildren have even become increasingly important over time (Bengtson 2001). In sum, this is positive evidence on the strength of intergenerational family relations; and it has led to the rejection of previous claims about a purported decline of the family (Szydlik and Künemund 2009).

However, in the United States of America (USA) and in many European countries, rates of childlessness have been on the rise, in some of these countries reaching high levels last seen in cohorts of women born around the turn of the 2oth century (Dykstra 2009; Kohli and Albertini 2009; Morgan 1991; Rowland 2007; Schnettler and Wöhler 2014). Thus, an increasing share of the population in these countries remains without the benefits of strong intergenerational family ties. This raises the question of how the personal and support networks of individuals without children are structured in comparison to those of parents. It also implies the questions of whether and how the childless can substitute the lack of support from adult children. Both have clear implications for welfare planning (cf. Albertini and Mencarini 2012): policy makers need an answer to these questions in order to both determine the current and future demand for formal care services and to understand how informal support relations can be fostered where they are absent.

Previous research has often focused on childlessness as a component of demographic change (e.g. Bloom and Trussell 1984; Dykstra and Hagestad 2007; Kaufmann et al. 1998, 2002; Sobotka 2008). Studies on the individual consequences of childlessness in later life, on the other hand, are scarce (DeOllos and Kapinus 2002). Furthermore, the few existing studies have often described the childless as a homogenous population of disadvantaged and stigmatised individuals (DeOllos and Kapinus 2002; Dykstra and Hagestad 2007; Kohli and Albertini 2009). Recent research has started to challenge this view and instead emphasises the diversity of causes for, and thus different pathways into, permanent childlessness, including such causes as infertility, structural barriers against combining career and family, temporary postponement of child-bearing turned permanent, and deliberate decisions against child-bearing (Abma and Martinez 2006; Bulcroft and Teachman 2004; Hagestad and Call 2007; Letherby 2002). Different pathways into permanent childlessness also imply different opportunities and constraints for building and maintaining social ties across the 
life course and thus differences in the availability of these ties as sources for social support in later life.

Here we want to answer the following questions: Do the childless substitute the lack of adult children in their personal and support networks? If so, what are the mechanisms for substitution? We examine two such mechanisms: The first one is substitution of potential supporters through adjustments in network size and composition. Full substitution of this kind would be given if the average number of children in the networks of parents were substituted by a higher number of alternative ties in the networks of the childless, for instance, a higher number of friends, thus resulting in equal network sizes between parents and the childless. The second mechanism is what we call substitution through increased tie 'efficiency'. Full substitution of this kind would be given if relatives, friends and acquaintances in the networks of the childless were more likely to be considered potential supporters than those in the networks of parents, thus leading to equal numbers of potential supporters even though the childless have smaller personal networks overall. Such differences in tie efficiency could, for instance, result from differences in friendship intensity or from normative expectations that parents could and should resort for help to their adult children when in need.

In reality, both types of substitution may occur, and, given changes in the degree and character of childlessness across cohorts, their relative impact may have changed over time (Kohli and Albertini 2009; Peuckert 2012; Rowland 2007; Schnettler and Wöhler 2014). For example, childlessness in older cohorts was largely involuntary given war-related shortages of men (Dykstra 2009; Hagestad and Call 2007; Schwarz 1997, 1999). But in more recent cohorts, reasons for childlessness have become more diverse: childlessness can be the result of voluntary lifestyle choices and involuntary childlessness due to medical and career-related reasons (Hagestad and Call 2007; Kaufmann et al. 1998, 2002; Nave-Herz 1988; Peuckert 2012; Ruckdeschel 2007; Thornton and Young-DeMarco 2001). These changes may be associated with shifting attitudes towards childlessness: in the USA, for instance, the acceptance of childlessness has improved since the 1970 (Koropeckyj-Cox and Pendell 2007). Changes in the prevalence of, and valence attributed to, childlessness arguably are tied to changing opportunities for building and maintaining strong ties to kin other than children or grandchildren (henceforth summarised as 'extended kin') and to non-kin like friends, acquaintances and neighbours. Specifically, we argue that the decreasing stigmatisation of childlessness should foster stronger ties to kin and non-kin across the lifecourse for individuals in younger birth cohorts. Also, the increasing prevalence of childlessness should boost opportunities to build strong ties to other childless individuals 


\section{Sebastian Schnettler and Thomas Wöhler}

that may play a role as supporters later in life. Therefore, both types of substitution should be more likely in more recent cohorts. In our own analysis, we thus include a comparison of substitution mechanisms across cohorts.

We restrict our analysis to Germany as a case in point, as in West Germany the recent trend of a renewed rise in childlessness has been most pronounced. Here, according to estimates, about 25 per cent of women born in 1960 are expected to remain permanently childless ( see Rowland 2007; Schnettler and Wöhler 2014). Our findings are relevant to other countries as well, given that the assumed mechanisms for substitution are more or less universal.

\section{Previous research}

\section{Networks and social support}

Previous research shows that, on average, childless individuals have smaller networks than parents in later life (Dykstra 1995, 20o6; Künemund and Hollstein 2000; Lang 2004; Schnettler 2008; Wenger, Scott and Patterson 2000). Part of this difference can be explained by the fact that a higher share of the childless remains single when compared to parents. Being single implies not only being without a partner but also being without a broader network of in-laws (Bien et al. 1996; Henretta, Grundy and Harris 2001; Wagner, Schütze and Lang 1996). The remaining difference in average network size between parents and the childless seems largely driven by the number of children and grandchildren in the personal networks of parents (Dykstra 1995, 2006; Lang 2004). Although extended kin and non-kin are somewhat more frequent in the networks of the childless, they are not frequent enough to substitute for the higher number of close kin in the networks of parents (Dykstra 20o6; Künemund and Hollstein 2000; Schnettler 2008).

The childless have less contact with relatives than parents, a difference largely driven by contact with children. There seems to be no systematic difference in contact frequency with other relatives than children and non-kin. This pattern is consistent across countries (Wenger et al. 2007). A longitudinal study with a focus on sibling ties shows that the childless do not have more frequent contact with their siblings than parents do (White 2001). The childless, however, more frequently than parents name extended kin and friends as companions and confidants (Connidis and Davies 1990). This finding is backed up by qualitative research that elucidates the important role of extended kin and non-kin in the networks of permanently childless older women (Rubinstein et al. 1991). 
When it comes to actual support, the childless, on average, report receiving less informal support than parents (Kohli and Albertini 20o9: 1178; Larsson and Silverstein 2004). Also, higher shares of the childless elderly rely on formal support in elder-care homes. This could be an indication that they lack informal supporters in their personal networks that would otherwise support them in their homes (Dykstra 2009; Koropeckyj-Cox and Call 2007). The difference in support availability between parents and the childless is moderated by health status: the childless receive similar amounts of support as parents when they are in good health, but receive less when they are in bad health (Albertini and Mencarini 2012; Wenger et al. 2007). The childless elderly also provide less informal support than parents (Kohli and Albertini 2009). This finding might lead to the assumption that the childless have more time and resources to spend on broader civic engagement and philanthropy than parents (Adloff 2009). But empirical evidence supports this assumption only partially. Whereas the childless contribute more voluntary work and make more charitable contributions (Kohli and Albertini 2009), they do not show stronger community participation than parents (Wenger et al. 2007).

\section{Mechanisms of substitution}

Scholars have focused on two models that are relevant for understanding the potential for substitution of missing supporters in personal networks: the model of functional specificity and the model of hierarchical compensation (Künemund and Hollstein 2000; Schnettler 2008). They differ in their emphasis of task- versus person-specific substitution processes (Cantor 1979; Lang 2004). First, the functional specificity model postulates that certain types of relationships are better suited to fulfil certain tasks. Neighbours, due to their proximity, for instance, are better suited to help with tasks that require a fast response. Close kin, on the other hand, are traditionally seen as responsible for tasks that require long-term help and intimacy (Cantor 1979). The postulated task-specialisation of personal ties implies that the potential for substitution is limited if close kin are not available (Künemund and Hollstein 2000; Schnettler 2008). Second, the hierarchical compensation model postulates a hierarchy according to which certain types of persons are preferred to fulfil a wide range of support tasks (Cantor 1979). Individuals lower in the preference order as supporters may serve as substitutes for individuals higher in the preference order if the latter do not exist in one's social network or if they are temporarily unavailable (Schnettler 2008: $3^{8-41)}$.

Künemund and Hollstein (2000) suggest a new model that integrates the model of functional specificity and the model of hierarchical compensation. 


\section{Sebastian Schnettler and Thomas Wöhler}

They argue that multiple steps are necessary, at least analytically, to infer actual exchange of support from the mere existence of a personal network: a particular person, preferred by the focal individual (ego) as potential helper, must exist in the personal network; that person needs to know about ego's need for support and be willing to provide support; ego needs to have a concrete need for a particular type of support; and the potential helper should be available at the right time and place and have the competences to provide the respective support needed (Künemund and Hollstein 2000). Given the contingencies at each of these analytical steps, the possibility of meeting the initial helper preference diminishes, the closer we move towards the step of actual support provision. Thus, at the end of the analytical pathway, it is likely that functional specificity predominates hierarchical compensation (Künemund and Hollstein 2000; Schnettler 2008: $3^{8-} 5^{6}$ ).

Ideally, therefore, substitution processes are to be examined at various steps in this analytical pathway. In the preceding section, we reported findings from previous research on separate steps in this pathway, including information on size and composition of personal networks, networks of potential supporters and networks of actual supporters. The result is that, on average, the childless fare somewhat worse than parents on most measures. An open question, however, is which mechanisms are responsible for the differences between the childless and parents at each of these steps. If the childless fare worse at any of the analytical steps outlined above, this could be the mere consequence of them having smaller networks in the first place. Or, controlling for network size and composition, it could be the consequence of a lower willingness or lower availability of persons in their personal networks to provide support, or a lower willingness to accept support from particular individuals in one's own personal network.

In this paper, we focus on part of the analytical pathway outlined above. Specifically, we ask if and how the network of potential supporters among parents and the childless can be explained by their overall personal networks. Also, we try to find out what the relative contribution of the two substitution mechanisms described in the introduction of this papersubstitution through network size/composition and substitution through higher tie efficiency - is in transforming the overall personal network into a network of potential supporters. To elucidate these mechanisms empirically, this involves two steps. First, the personal networks of the childless need to be compared to those of parents. Second, while statistically controlling for the size and composition of personal networks of parents and the childless, we need to analyse the degree to which each existing person is considered a potential supporter for individuals of either of these two groups. 
TAB LE 1. Overlap of age intervals by birth cohorts

\begin{tabular}{|c|c|c|c|c|c|c|}
\hline \multirow{2}{*}{$\begin{array}{l}\text { Survey } \\
\text { wave }\end{array}$} & \multicolumn{6}{|c|}{ Birth cohorts } \\
\hline & $1911-19^{19}$ & $1920-1929$ & $193^{0-1939}$ & $1940-1949$ & $195^{0-1959}$ & $1960-1968$ \\
\hline 1996 & $77-85$. & $67-76$ & $57-66$ & $47^{-} 5^{6}$ & $.40-46$ & - \\
\hline 2002 & $83-85$. & $73-82$ & $63-72$ & $53^{-62}$ & $43^{-} 5^{2}$ & $.40-42$ \\
\hline 2008 & - & $79-85$ & $69-78$ & $59-68$ & $49^{-} 5^{8}$ & $.40-48$ \\
\hline
\end{tabular}

Notes: Dark bars indicate overlap of adjacent age groups. '.' indicates censoring of age intervals. Source: German Ageing Survey $(\mathrm{N}=12,828)$, Waves 1-3.

\section{Data and methods}

The following analysis is based on a pooled cross-sectional data-set of the first three waves of the German Ageing Survey, administered in 1996, 2002 and 2008. The sample is stratified by age intervals $\left(4^{\mathrm{O}-}-54,55^{-69}\right.$, $70-85$ ), residence in West or East Germany, and gender (Kohli 2000; Künemund 2000; Motel-Klingebiel et al. 2010). Pooling of the three waves yields a sample of childless respondents and parents large enough to allow for a differentiated comparison of the social networks and support relationships of parents $(\mathrm{N}=12,774)$ and the permanently childless $(\mathrm{N}=$ $1,886)$. First-time parenthood after the age of 40 is very rare for both men and women (Schnettler 20o8; see Table 1 in Schnettler and Wöhler 2014). Thus, our sample provides a good representation of the permanently childless. Previous research shows that an association exists between residential proximity of parents and their adult children, and the frequency of contact and the exchange of support between them (Hays 1984; Mulder and Cooke 2009). We thus extend our comparison between parents and the childless by distinguishing two types of parents: 'remote parents', that is, those with all children living away more than two hours $(\mathrm{N}=4,437)$, and 'regional parents' with at least one child living less than two hours away $(\mathrm{N}=8,337)$. In the following, we work with a slightly smaller net sample that includes only cases without missing values on any of the variables in the multivariate models. The respective case numbers are $\mathrm{N}=1,608$ (childless), $\mathrm{N}=3,865$ (remote parents) and $\mathrm{N}=7,355$ (regional parents).

The German Ageing Survey includes a section with detailed information on personal networks and social support (Dittmann-Kohli et al. 1997: 6). Here, we focus on network size, composition and the perceived availability of social supporters in the personal social networks of respondents. The latter is restricted to two support dimensions: informational and emotional support. These are operationalised as the answers to the following questions, respectively: 'If you had to make an important personal decision, would you know of someone you could ask for advice?' and 'To 
whom could you turn when you need to be consoled or cheered up, e.g. when you are sad: Would you know of someone?' (Dittmann-Kohli et al. 1997: 73-6). The personal and support networks were measured as separate egocentric networks with a maximum of up to eight and five persons to be nominated by respondents, respectively.

Our analytical strategy is the following. After the presentation of descriptive results on the size and composition of personal and support networks of the childless and parents, we report the results of a series of Poisson regression models on the number of potential informational and emotional supporters. We start with a basic model that only includes dummy variables for parental status as main explanatory variables. Second, we add controls for gender, age (main and quadratic effect), region (East versus West Germany), income (natural $\log$ ), education, employment status and subjective health. This is to account for compositional differences between the three parental status groups. Third, we additionally control for partner status and the respective numbers of children, grandchildren, friends, acquaintances and extended kin. In this way, we can test how much the average difference in the number of potential supporters between parents and the childless is reduced by controlling for network size and composition. Fourth, we include an interaction of these indicators of network size and composition with parental status. This is to test if certain types of network members have a smaller or larger effect on the availability of potential supporters for parents and the childless. Thus, steps three and four allow us to dissect the relative contribution of the two hypothesised substitution mechanisms. Finally, in a fifth model, we add threeway interactions between indicators for network size and composition, parental status and birth cohort. This allows for testing how tie efficiency changes across cohorts, e.g. if the availability of existing friends as potential supporters increases or decreases for parents and the childless across different birth cohorts. In this last step, cohort effects should be interpreted with caution, though, as they are partially confounded with age effects. The survey years span 12 years, leaving some overlap of age groups within cohorts. Table 1 shows that adjacent age groups overlap, but non-adjacent age groups within cohorts do not intersect (indicated by dark shades). For the youngest and oldest birth cohorts no disjoined age groups are available, meaning that for them a distinction between age and cohort effects is most difficult.

\section{Results}

Descriptive findings

With on average $3.3^{8}$ individuals (rounded to two digits; standard error $(\mathrm{SE})=0.06)$, the childless have smaller networks than remote $\left(4.5^{1}\right.$; 
$\mathrm{SE}=0.04)$ and regional parents $(4.47 ; \mathrm{SE}=0.03)$. Partners and spouses are less frequent and extended kin and friends more frequent in the personal networks of the childless as compared to those of parents. Overall, this latter difference is not enough for the childless to fully substitute for the average number of children and grandchildren in the networks of parents. Important compositional differences can also be found between the two types of parents: remote parents have fewer children and grandchildren in their personal networks, but more friends and extended kin, than regional parents who have at least one child close by. Thus, the overall network size for both types of parents is about equal (see Figure 1, row 1). ${ }^{1}$ When we turn our attention from personal networks to the subset of individuals considered potential supporters for informational and emotional support, the overall pattern is very similar: childless respondents report having 1.91 ( $\mathrm{SE}=0.03)$ and $1.98(\mathrm{SE}=0.03)$ potential emotional and informational supporters on average, respectively; remote parents report having $2.18(\mathrm{SE}=0.02)$ and $2.27(\mathrm{SE}=0.02)$; and regional parents report having $2.23(\mathrm{SE}=0.02)$ and $2.35(\mathrm{SE}=0.02)($ see Figure 1 , row 2$) .^{2}$

Figure 2 shows the change of network size and composition for parents and the childless across cohorts. Network size has increased for all groups, but most steeply for remote parents. Whereas in older cohorts their average personal network size closely matches that of the childless, in younger cohorts it more closely matches that of regional parents. Despite the increases in the size of personal networks in all groups, the number of parents' potential supporters remains remarkably stable across cohorts, both with regard to emotional and informational support. For regional parents, the number of potential supporters remains constant at about two. Remote parents report an average of one and a half potential supporters in the oldest three cohorts, a number that rises up to two across the younger three cohorts. Remarkable is that the number of potential supporters increases most steeply for the childless. In this group, the number of potential informational or emotional supporters doubles from an average of about one to an average of about two persons, respectively, across cohorts. That is, whereas the childless in older cohorts clearly lack the same number of potential supporters as parents, in younger cohorts they fare as well as parents. This may partially reflect a real adjustment process across cohorts and partially an age effect, given that the lack of supporters is mostly felt in later life, that is, for those individuals in older cohorts.

In addition to this overall convergence across cohorts, we find considerable compositional changes in personal and support networks. For the childless, the increases in personal network size and the number of potential supporters seem mainly driven by an increase in the number of friends and 


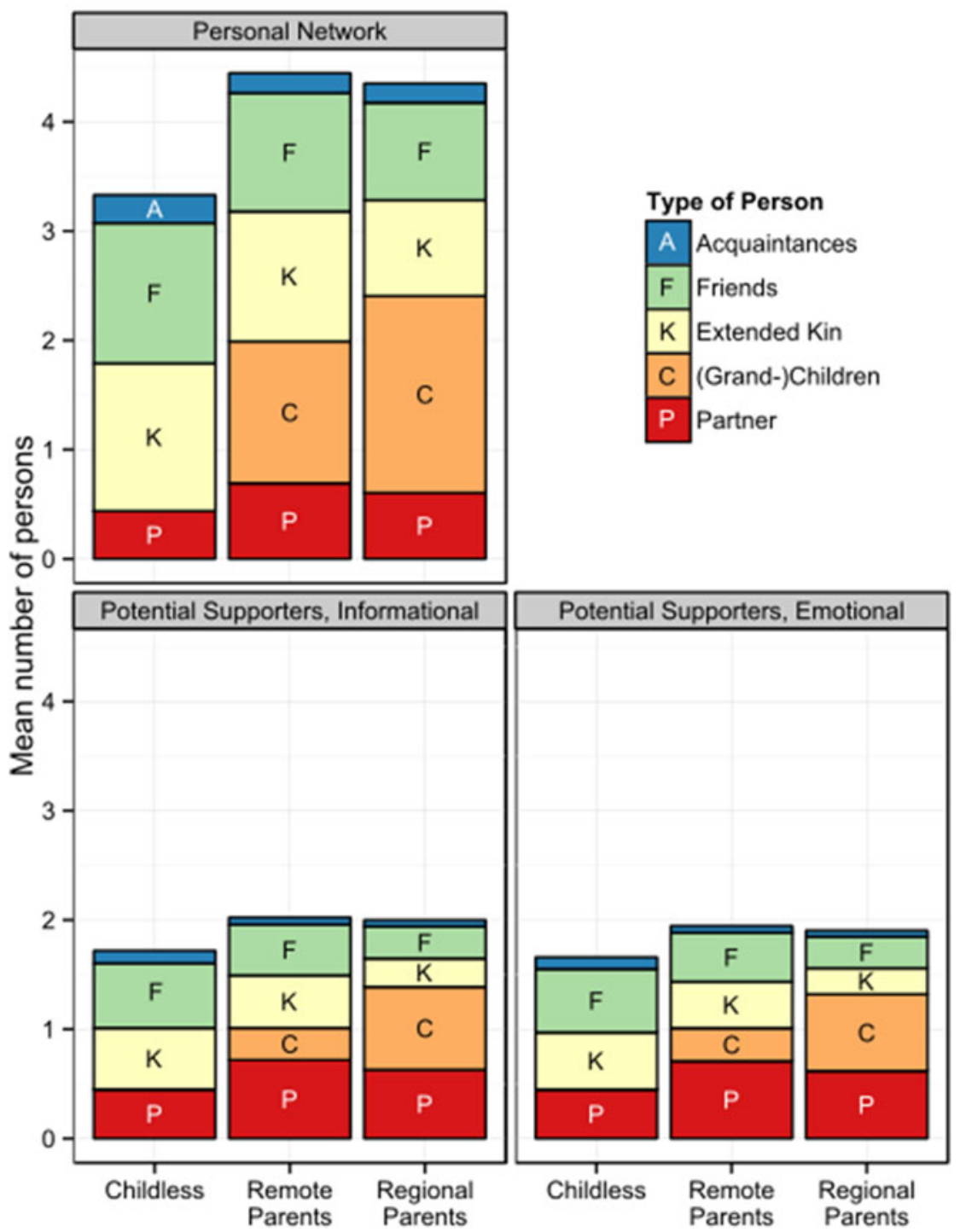

Figure 1. Network size and composition in personal and potential support networks.

Source: German Ageing Survey $(\mathrm{N}=12,828)$; mean values, weighted by age, region and gender.

extended family members. For parents, we find that children (and grandchildren) play a decreasing role as potential supporters across cohorts. This decrease is balanced by an increasing importance of extended kin, friends and acquaintances, thus leaving the size of support networks relatively stable across cohorts. Independent of birth cohort, the group of acquaintances numerically plays a negligible role in the personal and 


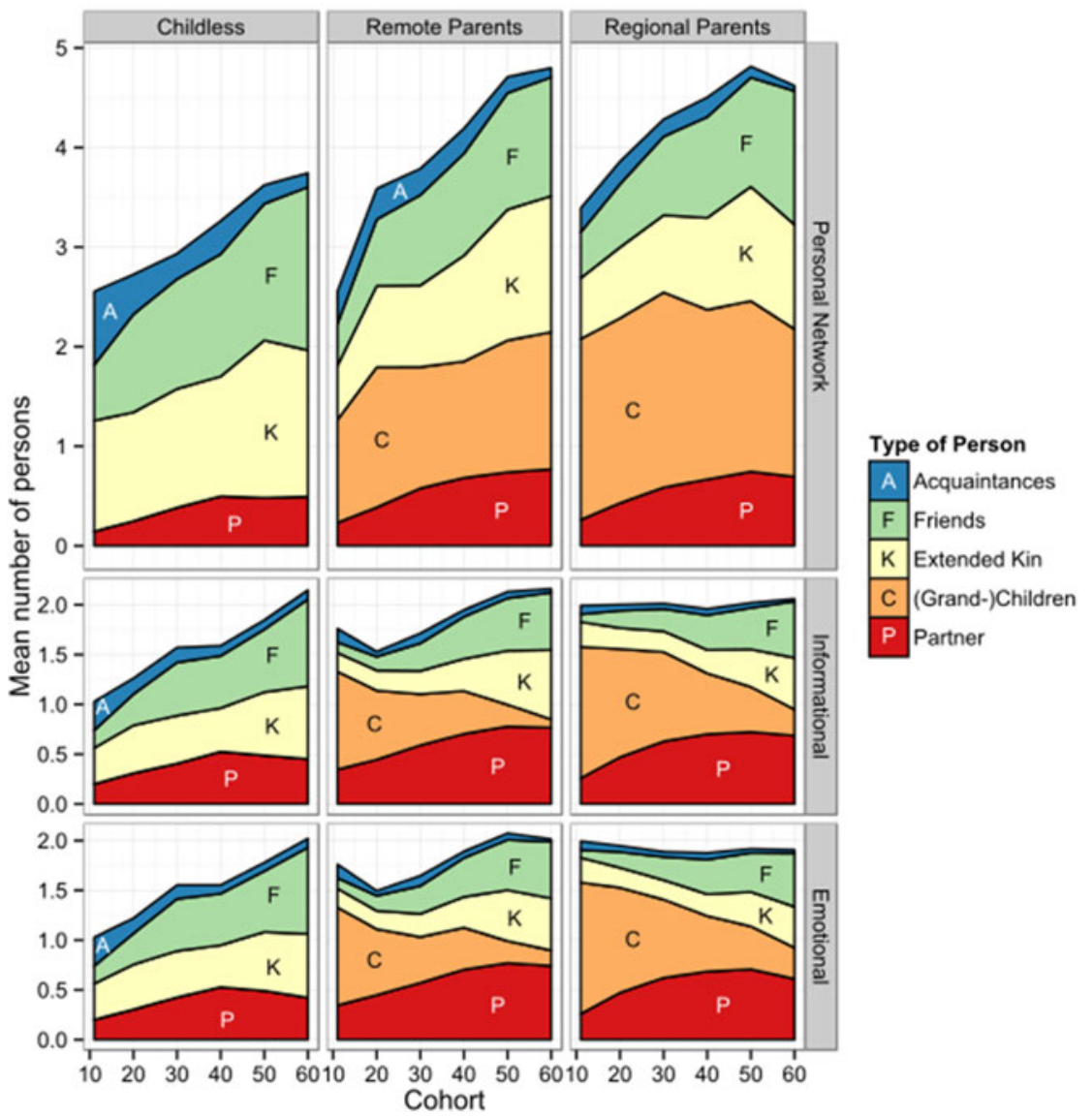

Figure 2. Network size and composition in personal and potential support networks across cohorts.

Source. German Ageing Survey $(\mathrm{N}=12,828)$; mean values across cohorts (1911-1919, 19201929, 1930-1939, 1940-1949, 1950-1959, 1960-1968), weighted by age, region and gender.

support networks of parents and the childless. Thus, the following analysis focuses only on friends and extended kin as potential supporters.

\section{Multiple regression analysis}

In the following, we report average marginal effects (AMEs). These are easily interpretable as marginal, or, in the case of categorical variables, discrete, changes in the number of potential supporters per unit-change in the explanatory variable (Auspurg and Hinz 2011; Bartus 2005; Mood 2010). We start with the results of a series of regression models on the number of potential informational supporters (see Table 2). The results from 
T A B L E 2. Poisson regression on number of potential informational supporters

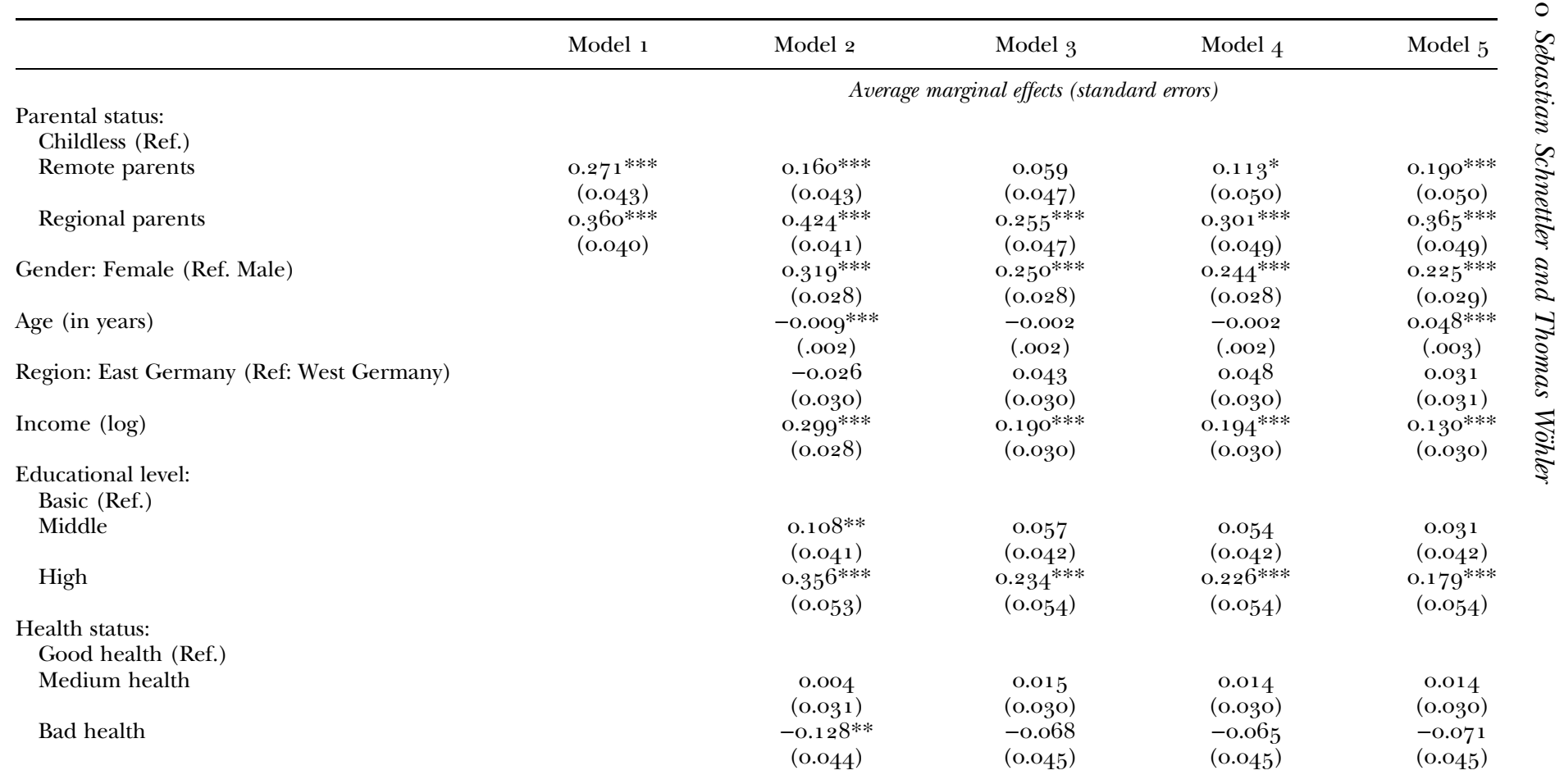


Employment status:

Employed (Ref.)

Retired

Not employed

0.055

(o.049)

(o.049)

0.035

(o.043)

$(0.044)$
$0.203^{*} * *$

(o.031)

(o.049)

0.041

Partner status: Yes $=1$

(o.044)

$0.193^{* * *}$

0.055

(0.045)

$0.15^{6 * * *}$

Network:

Number of children and grandchildren

$0.157^{* * *}$

(o.032)

Number of other family

Number of friends

(0.010)

$0.155^{* * * *}$

(0.010)

$0.169 * * *$

$0.159^{* * * *}$

(0.010)

$0.223^{* * * *}$

(0.010)

$0.216 * * *$

Number of acquaintances

(o.oog)

(o.oog)

(0.021)

0.068

Year of birth

(o.022)

Likelihood ratio $\chi^{2}$

$0.143^{* * *}$

(0.011)

$0.167 * * *$

(0.010)

$0.203^{* * *}$

(o.oog)

$0.132 * * *$

(0.023)

$0.052 * * *$

(o.003)

$2,130.12$

12,828

Note: Ref.: reference group.

Source: German Ageing Survey $(\mathrm{N}=12,828)$, Waves 1-3.

Significance levels: $* p<0.05, * * p<0.01, * * * p<0.001$. 


\section{$135^{2}$ Sebastian Schnettler and Thomas Wöhler}

Model 1 roughly reproduce the mean differences reported above. That is, with an average of $1.91(\mathrm{SE}=0.04)$ informational supporters, the childless have $0.27(\mathrm{SE}=0.04)$ and $0.36(\mathrm{SE}=0.04)$ supporters less than remote and regional parents, respectively. Adding controls for socio-economic status, demographic variables and subjective health status reduces the difference between the childless and remote parents slightly (Model 2; AME = $0.16 ; \mathrm{SE}=0.04)$, but it pronounces the differences to regional parents $(\mathrm{AME}=0.42 ; \mathrm{SE}=0.04)$. Adding controls for the size and composition of the personal network reduces the difference between the childless and remote (Model 3; $\mathrm{AME}=0.06 ; \mathrm{SE}=0.05)$ and regional parents $(\mathrm{AME}=$ $0.26 ; \mathrm{SE}=0.05$ ). The difference between the childless and remote parents ceases to be statistically significant. That is, the difference between these two groups can be explained mostly by taking into account compositional differences between them. For emotional support, the overall patterns of results are very similar to those for informational support (see Table 3 ).

In Model 4, we allow the effects of network composition to vary by parental status (two-way interaction). To facilitate interpretation of the interaction effects, we display the results graphically. Given that we report AMEs instead of incidence rate ratios, interaction effects are not shown in Tables 2 and 3. These are instead presented in the supplementary online material along with the respective incidence rate ratios ( see Supplementary Tables 1 and 2).

For the childless, the effect each extended family member has on the number of available informational supporters is significantly stronger than it is for regional parents. But there is no statistically significant difference in comparison to remote parents. In contrast, the effect each friend has on the number of potential informational supporters is higher for the childless than for both types of parents. Also the effect sizes do not differ significantly between the two types of parents (see Figure 3, left panel). This pattern in the effects of friends and extended kin is very similar with regard to the number of potential emotional supporters (see Figure 3, right panel). Taken together, these results indicate that the childless partially substitute for the non-existing social support of children through a higher tie efficiency of their extended kin and friendship ties. It should be noted, however, that it takes on average two to three friends- or a similar number of extended kin-in the personal networks of the childless to match the number of predicted supporters of parents (see Schnettler and Wöhler 2014).

In Model 5 , we add three-way interactions between indicators of network size and composition, parental status and birth cohort. The resulting coefficients indicate whether the effect each type of person has on the number of potential supporters for parents and the childless changes across cohorts. 
T A B L E 3. Poisson regression on number of potential emotional supporters

\begin{tabular}{|c|c|c|c|c|c|}
\hline & Model 1 & Model 2 & Model 3 & Model 4 & Model 5 \\
\hline & \multicolumn{5}{|c|}{ Average marginal effects (standard errors) } \\
\hline \multicolumn{6}{|l|}{$\begin{array}{l}\text { Parental status: } \\
\text { Childless (Ref) }\end{array}$} \\
\hline Remote parents & $\begin{array}{c}0.267^{* * *} \\
(0.042)\end{array}$ & $\begin{array}{c}0.15^{6 * * *} \\
(0.042)\end{array}$ & $\begin{array}{c}0.059 \\
(0.046)\end{array}$ & $\begin{array}{c}0.092 \\
(0.049)\end{array}$ & $\begin{array}{l}0.148^{* *} \\
\left(0.05^{0}\right)\end{array}$ \\
\hline Regional parents & $\begin{array}{c}0.315^{* * *} \\
(0.039)\end{array}$ & $\begin{array}{c}0.396^{* * * *} \\
(0.040)\end{array}$ & $\begin{array}{c}0.235^{* * *} \\
(0.046)\end{array}$ & $\begin{array}{c}0.262 * * * \\
(0.048)\end{array}$ & $\begin{array}{c}0.311 * * * \\
(0.048)\end{array}$ \\
\hline Gender: Female (Ref. Male) & & $\begin{array}{c}0.3^{80} 0^{* * * *} \\
(0.027)\end{array}$ & $\begin{array}{c}0.3^{16 * * *} \\
(0.028)\end{array}$ & $\begin{array}{c}0.310^{* * * *} \\
(0.028)\end{array}$ & $\begin{array}{c}0.300^{* * * *} \\
(0.028)\end{array}$ \\
\hline Age (in years) & & $\begin{array}{c}-0.011 * * * \\
(0.002)\end{array}$ & $\begin{array}{c}-0.004^{*} \\
(0.002)\end{array}$ & $\begin{array}{c}-0.004^{*} \\
(0.002)\end{array}$ & $\begin{array}{c}0.025^{* * * *} \\
(0.003)\end{array}$ \\
\hline Region: East Germany (Ref: West Germany) & & $\begin{array}{c}-0.074^{*} \\
(0.030)\end{array}$ & $\begin{array}{l}-0.010 \\
(0.030)\end{array}$ & $\begin{array}{l}-0.006 \\
(0.030)\end{array}$ & $\begin{array}{l}-0.014 \\
(0.030)\end{array}$ \\
\hline Income $(\ln )$ & & $\begin{array}{c}0.263^{* * *} \\
(0.028)\end{array}$ & $\begin{array}{c}0.160^{* * * *} \\
(0.029)\end{array}$ & $\begin{array}{c}0.161 * * * \\
(0.029)\end{array}$ & $\begin{array}{c}0.126^{* * * *} \\
(0.029)\end{array}$ \\
\hline $\begin{array}{l}\text { Educational level: } \\
\text { Basic (Ref.) }\end{array}$ & & & & & \\
\hline Middle & & $\begin{array}{l}0.070 \\
(0.040)\end{array}$ & $\begin{array}{c}0.023 \\
(0.041)\end{array}$ & $\begin{array}{l}0.020 \\
(0.041)\end{array}$ & $\begin{array}{c}0.008 \\
(0.041)\end{array}$ \\
\hline High & & $\begin{array}{l}0.304^{* * *} \\
\left(0.05^{2}\right)\end{array}$ & $\begin{array}{c}0.194^{* * * *} \\
(0.053)\end{array}$ & $\begin{array}{c}0.187 * * * \\
(0.053)\end{array}$ & $\begin{array}{l}0.160 * * \\
(0.053)\end{array}$ \\
\hline $\begin{array}{l}\text { Health status: } \\
\quad \text { Good health (Ref.) }\end{array}$ & & & & & \\
\hline Medium health & & $\begin{array}{l}-0.016 \\
(0.030)\end{array}$ & $\begin{array}{l}-0.008 \\
(0.030)\end{array}$ & $\begin{array}{l}-0.009 \\
(0.030)\end{array}$ & $\begin{array}{l}-0.010 \\
(0.030)\end{array}$ \\
\hline Bad health & & $\begin{array}{c}-0.140^{* *} \\
(0.043)\end{array}$ & $\begin{array}{l}-0.085 \\
(0.044)\end{array}$ & $\begin{array}{l}-0.081 \\
(0.044)\end{array}$ & $\begin{array}{l}-0.081 \\
(0.044)\end{array}$ \\
\hline
\end{tabular}


TABLE $3 \cdot$ ( Cont.)

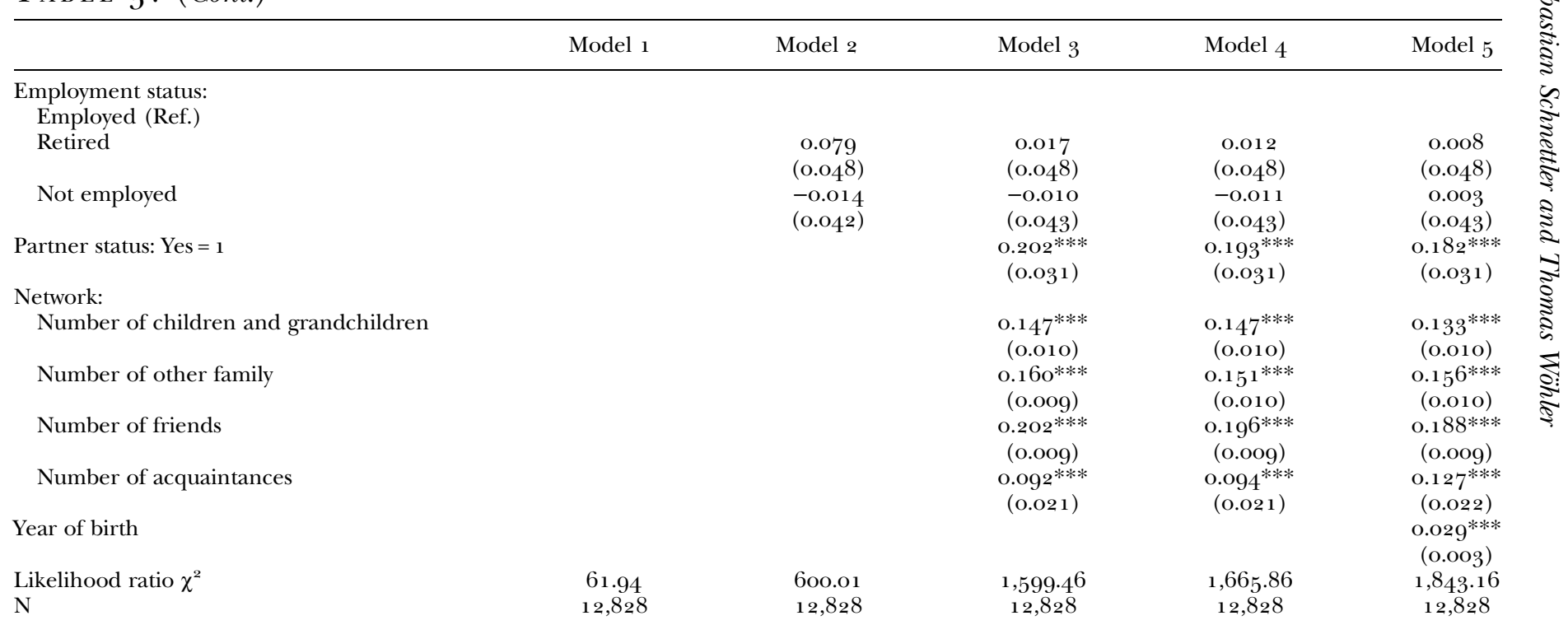

Note: Ref.: reference group.

Source: German Ageing Survey ( $=12,828)$, Waves 1-3.

Significance levels: $* p<0.05, * * p<0.01, * * * p<0.001$. 


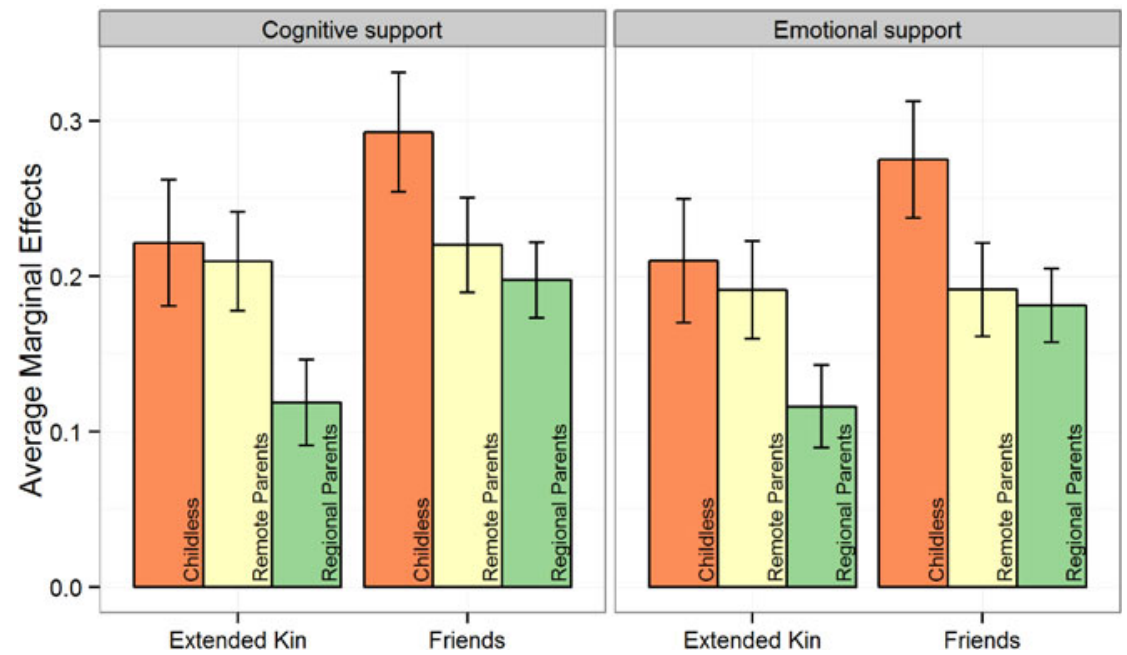

Figure 3. Average marginal effects (AME) and 95\% confidence intervals of personal network on potential support, by parental status.

Source: German Ageing Survey $(\mathrm{N}=12,828)$; AME based on Model 4 (see Table 2 and Supplementary Table 1).

Here we treat birth cohort as a continuous variable. A comparison with a different model in which cohort status was treated as a categorical variable confirms the linear effect of cohort status (not reported here). Figure 4 projects the results of the three-way interactions into two dimensions, averaging over the number of extended kin or friends in the respective parental status groups. Across cohorts, the effect of these types of personal ties on the number of potential informational supporters has increased for the childless and both types of parents alike. But in older cohorts, the difference between the childless and parents is more pronounced than in younger cohorts. Parents in younger cohorts seem to have caught up with the childless in the effects existing friends and extended kin have on the number of potential informational supporters. The effects of extended kin are similar for the childless and remote parents across all cohorts (see Figure 4, row 1 ). Again, all patterns described so far for informational support apply similarly for emotional support. The difference is that the changes over time are not as pronounced in the latter case ( see Figure 4, row 2).

\section{Discussion}

Drawing on data from three waves of the German Ageing Survey, we compared the personal and support networks of permanently childless 


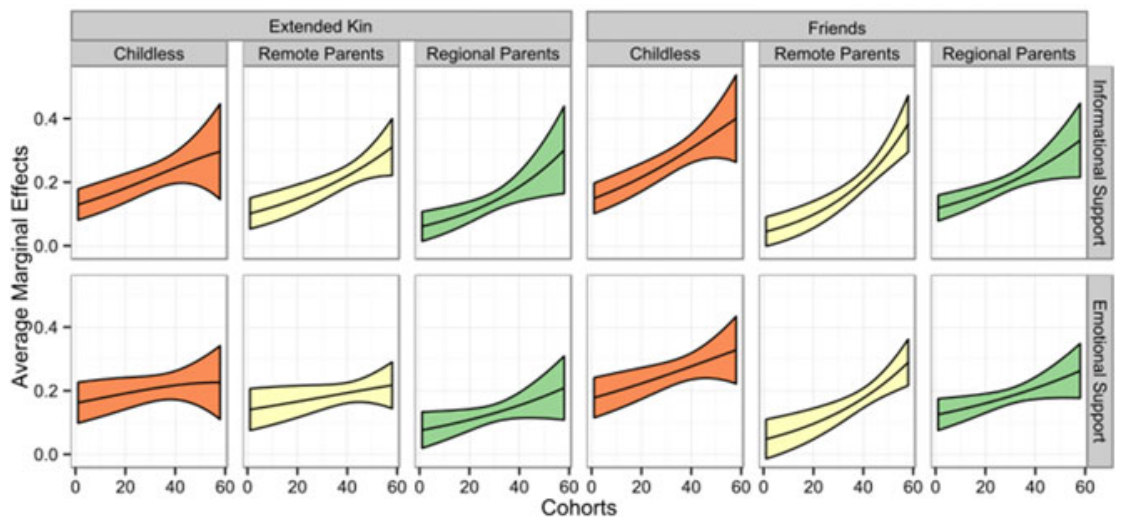

Figure 4. Average marginal effects (AME) and 95\% confidence bands of personal network on potential support, by year of birth.

Source: German Ageing Survey $(\mathrm{N}=12,828$ ); AME based on Model 5 (see Table 3 and Supplementary Table 2).

individuals with those of remote parents whose children all live more than two hours away and with regional parents who have at least one child nearby. We argued that previous research has not convincingly answered the question about which mechanisms, if at all, allow the childless to substitute for the non-existence of adult children in their support networks. Yet, this knowledge about mechanisms is essential for social scientists to derive better predictions on how current demographic trends will affect future scenarios of social support in later life. Furthermore, for policy makers such information on the potential of substitution importantly adds to existing descriptive accounts of the networks of parents and childless. It allows individuals who are most strongly in need of formal care services to be targeted better, as well as to provide a better understanding of the hidden potential for informal care that exists in individuals' personal networks and of the conditions under which this potential might be activated. Our approach to distinguish between substitution through network size and composition and substitution through different tie efficiencies was to examine potential support networks while controlling for size and composition of personal networks.

Our descriptive results confirm previous research in showing that the permanently childless do indeed have smaller personal networks and fewer potential supporters than parents. Although the number of extended kin and friends in their personal networks is slightly higher than in the networks of parents, this is not sufficient to substitute for the difference in average network size. The relative disadvantage of the childless as compared to parents is smaller when it comes to the number of potential supporters. 
This descriptive observation of a closing gap between parents and the childless when moving from personal networks to the subset of potential supporters therein is a hint at the possibility that the childless experience a higher tie efficiency than parents. This is confirmed in the multivariate analysis: controlling for compositional differences between parental status groups and their actual network size and composition, each friend and each member of extended kin have a larger effect for the childless than for parents. An important difference exists, however, with regard to the type of personal tie: the effect of friends on the number of potential supporters is higher for the childless when compared to both types of parents, but the effect of extended kin is higher only in comparison with regional parents who have at least one child nearby. Although both types of parents have similar network sizes, on average the composition and tie efficiency of their networks differ considerably. In fact, remote parents whose children all live farther away seem to be a mixed type, combining characteristics of the networks of the childless and those of regional parents. The comparison of the childless with these two types of parents thus emphasises the existence of diversity in later-life support networks and shows that the difference between parents and the childless is more of a gradual kind than often assumed.

The comparison across cohorts reveals the changing impact of the two substitution mechanisms. But, as we noted earlier, we cannot clearly distinguish between age and cohort effects with the current data. The observed changes could thus reflect changes in the relative importance of the two substitution mechanisms across cohorts, across age groups or a mix of both. An interpretation as cohort effect would suggest a decreasing disadvantage of the childless in the number of potential supporters towards younger cohorts. This interpretation would further suggest important compositional differences in the support networks of parents: a decreasing role of children as potential supporters would be mirrored by an increasing role of friends and extended kin. The multivariate results would suggest that the relative advantage of the childless in the efficiency of each friend and extended kin tie diminished towards younger cohorts. The overall interpretation would thus be that across cohorts the relative importance of substitution through network size increased over that of substitution through tie efficiency. However, an interpretation of the above changes as age effects suggests a different story. In this case, one could interpret the smaller differences between the childless and parents at younger ages as a consequence of the fact that respondents have not yet reached an age when support needs are salient and differences in support potential have become apparent. At higher ages, however, the two groups grow more different in terms of both network size/composition and tie efficiency. 


\section{$135^{8}$ Sebastian Schnettler and Thomas Wöhler}

Thus, the overall interpretation would be that the decrease in the size of support networks of the childless is offset partially by increases in tie efficiency across age groups. Future research should try to disentangle age and cohort effects better, once data on additional survey waves become available in upcoming years.

The current study has a number of limitations. Earlier, we argued that getting from the size and composition of personal networks to the actual exchange of support is, at least analytically, a multi-step process. With the examination of personal networks and the number of potential supporters, we focused on only one part of this process. Therefore, similar analyses as we presented here should be conducted with regard to other steps in this process, e.g. the pathway from potential support availability to actual support provision. Whereas we could argue that individuals have a solid impression of who they can count on as potential supporters based on their experience of previous interactions, it could be as well that individuals tend to overestimate their support potential in situations when they do not yet require support. Given the looser character of friendship as opposed to close kinship and given the distinct requirements for reciprocity in the two types of relationships, it could be that the situational requirements for support provision to childless individuals are higher than for support from children to their parents. Also, given the conditionality of the support situation of the childless on their state of health and frailty (e.g. Albertini and Mencarini 2012), friends likely play a bigger role for the healthy and mobile than for the unhealthy and frail.

Our focus on informational and emotional support also leaves us with limited insights into the relative importance of functional specificity versus hierarchical compensation. The substitution effects we find indicate some degree of hierarchical compensation. Hierarchical compensation on the level of potential support works both with regard to lifetime and temporary non-availability of adult children. This is indicated by the higher tie efficiency of extended kin for the childless and parents with no residentially proximate children when compared against parents with at least one child nearby. However, only the childless have a higher tie efficiency of friendship than the latter type of parents, whereas the two types of parents do not differ significantly from each other in this respect. This indicates a potential lifecourse effect: at least some childless individuals - that is, those who voluntarily decide for, or who are faced with, involuntary permanent childlessness early on in their lives - may be able to invest more in their friendships than both types of parents. The similarity of all results for informational and emotional support speaks against functional specificity. With our examination of personal and potential support networks, our analysis focuses on the beginning of the analytical pathway between networks and actual 
support exchange outlined above. Our findings are thus consistent with the model of Künemund and Hollstein (2000), which emphasises that hierarchical compensation should be predominant at early steps in this pathway, but functional specificity should become dominant in later steps. It is likely that results on substitution mechanisms look very different for instrumental and financial support because these types of support imply different opportunity structures than informational and emotional support. Therefore, similar analyses to the ones conducted in this paper should be repeated for additional types of support.

Another important limitation of the current study, one that it shares with many other studies based on surveys of people in later life, is its focus on the residential population. Previous research has found that the childless are over-represented in elder-care facilities (Dykstra 2009; Koropeckyj-Cox and Call 2007). Therefore, the childless respondents in our sample are positively selected. This makes the average differences in network size between parents and the childless appear smaller than they likely are in a fully representative sample of the elderly which includes both the institutionalised and residential population. A similar selection may be present in the effect sizes of friendship and extended kin on the number of potential supporters. If the childless in elder-care homes are less likely to consider their friends as potential supporters, then including the institutionalised population in an analysis would decrease the effects of substitution through efficiency.

Finally, our study is limited to the case of Germany. Recent birth cohorts of women in West Germany have one of the highest rates of childlessness in a cross-national comparison (Rowland 2007). This allowed us to provide a fine-grained analysis of the substitution mechanisms analysed based on data from a general social survey of the elderly population in Germany. Although substitution through network size and composition and substitution through higher tie efficiency can be regarded as general mechanisms that should be found to work in other countries as well, the degree to which these mechanisms align the size of networks and exchange of social support of parents and the childless likely varies with a range of additional factors, namely social support norms, availability of formal support for the elderly, attitudes and beliefs about childlessness, and the demographic opportunity structure for building and maintaining social support relationships. All of these factors differ cross-nationally. For instance, in some countries, negative stereotypes against the childless prevail (Letherby 2002; Yang and Rosenblatt 2008). Also demographic patterns and care regimes differ considerably, even within the European Union (Bettio and Plantenga 2004; Frejka and Sobotka 20o8; Sobotka and Toulemon 2008). Cross-national research could shed light on how both mechanisms of substitution outlined in this paper play out under these different circumstances. 


\section{NOTES}

1 The mean numbers of persons in Figure 1, distinguished by type of relationship, do not add up to the totals cited in the text. This is due to missing information on the relationship type for some members in respondents' networks. These missing network members are not included in Figure 1 and subsequent figures.

2 See Note 1 for details on why the numbers cited in the text may slightly deviate from the numbers underlying Figure 1.

\section{Acknowledgements}

SS worked on the conception and design of the study. TW and SS conducted the data analysis and prepared the tables and figures. SS wrote the manuscript with input from TW, and both SS and TW revised the manuscript critically and approved the final version to be published. The authors declare no conflicts of interest. This research is based on secondary analysis of survey data, thus no ethical approval was necessary.

\section{References}

Abma, J. C. and Martinez, G. M. 20o6. Childlessness among older women in the United States: trends and profiles. Journal of Marriage and Family, 68, 4, $1045^{-} 5^{6 .}$

Adloff, F. 2009. What encourages charitable giving and philanthropy? Ageing $\mathcal{E}^{\circ}$ Society, 29, 8, $1185^{-205}$.

Albertini, M. and Mencarini, L. 201 2. Childlessness and support networks in later life: new pressures on familistic welfare states? Journal of Family Issues, 35, 3, $33^{1-57}$.

Auspurg, K. and Hinz, T. 2011 . Gruppenvergleiche bei Regressionen mit binären abhängigen Variablen - Probleme und Fehleinschätzungen am Beispiel von Bildungschancen im Kohortenverlauf. Zeitschrift für Soziologie, 4o, 1, 62-73.

Bartus, T. 2005. Estimation of marginal effects using margeff. The Stata Journal, 5, 3, 309-29.

Bengtson, V. L. 2001. Beyond the nuclear family: the increasing importance of multigenerational bonds. Journal of Marriage and Family, 63, 1, 1-16.

Bettio, F. and Plantenga, J. 2004. Comparing care regimes in Europe. Feminist Economics, 10, 1, $85^{-113 .}$

Bien, W., Bayer, H., Bauereiß, R. and Dannenbeck, C. 1996. Die soziale Lage von Kinderlosen. In Bien, W. (ed.), Familie an der Schwelle zum neuen Jahrtausend: Wandel und Entwicklung familialer Lebensformen. Leske + Budrich, Opladen, Germany, 97-105.

Bloom, D. E. and Trussell, J. 1984. What are the determinants of delayed childbearing and permanent childlessness in the United States? Demography, 2 1, 4, 591-61 1.

Bulcroft, R. and Teachman, J. 2004. Ambiguous contructions. Development of a childless or child-free life course. In Coleman, M. and Ganong, L. H. (eds), Handbook of Contemporary Families: Considering the Past, Contemplating the Future. Sage, Thousand Oaks, California, $116-35$. 
Cantor, M. H. 1979. Neighbors and friends. An overlooked resource in the informal support system. Research on Aging, 1, 4, 434-63.

Connidis, I. A. and Davies, L. 1990. Confidants and companions in later life: the place of family and friends. Journal of Gerontology, 45, 4, S141-9.

DeOllos, I. Y. and Kapinus, C. A. 2002. Aging childless individuals and couples: suggestions for new directions in research. Sociological Inquiry, 72, 1, 72-80.

Dittmann-Kohli, F., Kohli, M., Künemund, H., Motel, A., Steinleitner, C. and Westerhof, G. 1997. Lebenszusammenhänge, Selbst- und Lebenskonzeptionen. Erhebungsdesign und Instrumente des Alters-Survey. Free University, Berlin, Germany.

Dykstra, P.A. 1995. Network composition. In Knipscheer, C. P. M., de Jong Gierveld, J., van Tilburg, T. G. and Dykstra, P. A. (eds), Living Arrangements and Social Networks of Older Adults. VU University Press, Amsterdam, 97-1 14.

Dykstra, P. A. 2006. Off the beaten track: childlessness and social integration in late life. Research on Aging, 28, 6, 749-67.

Dykstra, P. A. 2009. Childless old age. In Uhlenberg, P. (ed.), International Handbook of Population Aging. Springer, Wiesbaden, Germany, 671-9o.

Dykstra, P. A. and Hagestad, G. O. 2007. Roads less taken: developing a nuanced view of older adults without children. Journal of Family Issues, 28, 10, $1275^{-3} 10$.

Fergusson, E., Maughan, B. and Golding, J. 2008. Which children receive grandparental care and what effect does it have? Journal of Child Psychology and Psychiatry, 49, $2,161-9$.

Frejka, T. and Sobotka, T. 20o8. Overview Chapter 1: fertility in Europe: diverse, delayed and below replacement. Demographic Research, 19, 1, 15-46.

Hagestad, G. O. and Call, V. R. A. 2007. Pathways to childlessness: a life course perspective. Journal of Family Issues, 28, 10, 1338-61.

Hays, J. A. 1984. Aging and family resources: availability and proximity of kin. The Gerontologist, 24, 2, 149-53.

Henretta, J. C., Grundy, E. and Harris, S. 2001. Socioeconomic differences in having living parents and children: a U.S.-British comparison of middle-aged women. Journal of Marriage and Family, 63, 3, 852-67.

Hoff, A. 2007. Patterns of intergenerational support in grandparent-grandchild and parent-child relationships in Germany. Ageing E् Society, 27, 5, 643-65.

Kaufmann, F.-X., Kuijsten, A., Schulze, H.-J. and Strohmeier, K. P. (eds) 1998. Family Life and Family Policies in Europe. Volume I, Structures and Trends in the I980s. Oxford University Press, New York.

Kaufmann, F.-X., Kuijsten, A., Schulze, H.-J. and Strohmeier, K. P. (eds) 2002. Family Life and Family Policies in Europe. Volume 2, Problems and Issues in Comparative Perspective. Oxford University Press, New York.

Kohli, M. 200o. Der Alters-Survey als Instrument wissenschaftlicher Beobachtung. In Kohli, M. and Künemund, H. (eds), Die zweite Lebenshälfte. Gesellschaftliche Lage und Partizipation im Spiegel des Alters-Survey. Leske + Budrich, Opladen, Germany, 10-32.

Kohli, M. and Albertini, M. 2009. Childlessness and intergenerational transfers: what is at stake? Ageing $\mathcal{E}$ Society, 29, 8, $1171-1183$.

Kohli, M. and Künemund, H. (eds) 200o. Die zweite Lebenshälfte. Gesellschaftliche Lage und Partizipation im Spiegel des Alters-Survey. Leske + Budrich, Opladen, Germany.

Koropeckyj-Cox, T. and Call, V. R. A. 2007. Characteristics of older childless persons and parents: cross-national comparisons. Journal of Family Issues, 28, 10, 1362-414.

Koropeckyj-Cox, T. and Pendell, G. 2007. The gender gap in attitudes about childlessness in the United States. Journal of Marriage and Family, 69, 4, 899-915. 


\section{Sebastian Schnettler and Thomas Wöhler}

Künemund, H. 200o. Datengrundlage und Methoden. In Kohli, M. and Künemund, H. (eds), Die zweite Lebenshälfte. Gesellschaftliche Lage und Partizipation im Spiegel des Alters-Survey. Leske + Budrich, Opladen, Germany, 33-40.

Künemund, H. and Hollstein, B. 20oo. Soziale Beziehungen und Unterstützungsnetzwerke. In Die zweite Lebenshälfte. Gesellschaftliche Lage und Partizipation im Spiegel des Alters-Survey. Leske + Budrich, Opladen, Germany, 21 2-76.

Lang, F. R. 2004. The availability and supportive functions of extended kinship ties in later life: evidence from the Berlin Ageing Study. In Harper, S. (ed.), Families in Ageing Societies: A Multi-disciplinary Approach. Oxford University Press, Oxford, $64-81$.

Larsson, K. and Silverstein, M. 2004. The effects of marital and parental status on informal support and service utilization: a study of older Swedes living alone. Journal of Aging Studies, 18, 2, 231-44.

Letherby, G. 2002. Childless and bereft? Stereotypes and realities in relation to 'voluntary' and 'involuntary' childlessness and womanhood. Sociological Inquiry, 72, 1, 7-20.

Lye, D. N. 1996. Adult child-parent relationships. Annual Review of Sociology, 22, 1 , 79-102.

Mood, C. 2010. Logistic regression: why we cannot do what we think we can do, and what we can do about it. European Sociological Review, 26, 1, 67-82.

Morgan, S. P. 1991. Late nineteenth- and early twentieth-century childlessness. American Journal of Sociology, 97, 3, 779-8o7.

Motel-Klingebiel, A., Wurm, S., Engstler, H., Huxhold, O., Jürgens, O., Mahne, K., Schöllgen, I., Wiest, M. and Tesch-Römer, C. 2010. German Ageing Survey (DEAS): The Second Half of Life. Research Instruments of the Third Wave. German Centre of Gerontology, Berlin, Germany.

Mulder, C. H. and Cooke, T. J. 2009. Family ties and residential locations. Population, Space and Place, 15, 4, 299-304.

Nave-Herz, R. 1988. Kinderlose Ehen: eine empirische Studie über die Lebenssituation kinderloser Ehepaare und die Gründe für ihre Kinderlosigkeit. Juventa, Weinheim, Germany.

Peuckert, R. 2012. Ein Leben ohne Kinder: Kinderlosigkeit in Deutschland. In Familienformen im sozialen Wandel. Eighth edition, Springer, Wiesbaden, Germany, 249-70.

Rossi, A. S. and Rossi, P. H. 1990. Of Human Bonding: Parent/Child Relations Across the Life Course. Aldine De Gruyter, New York.

Rowland, D. T. 2007. Historical trends in childlessness. Journal of Family Issues, 28, 10 , $13^{11-37}$.

Rubinstein, R. L., Alexander, B. B., Goodman, M. and Luborsky, M. 1991. Key relationships of never married, childless older women: a cultural analysis. Journal of Gerontology, 46, 5, S270-7.

Ruckdeschel, K. 2007. Der Kinderwunsch von Kinderlosen. Zeitschrift für Familienforschung, 19, 2, 210-30.

Schnettler, S. 2008. Ohne Kinder alt werden. VDM, Saarbrücken, Germany.

Schnettler, S. and Wöhler, T. 2014. On the compensating role of friendship for parents and non-parents in later life. In Löw, M. (ed.), Vielfalt und Zusammenhalt. Verhandlungen des 36. Kongresses der Deutschen Gesellschaft für Soziologie in Bochum 20I 2. Campus, Frankfurt am Main, Germany, 1-26.

Schwarz, K. 1997. 100 Jahre Geburtenrückgang. Zeitschrift für Bevölkerungswissenschaft, 22, 4, 481-91.

Schwarz, K. 1999. Rückblick auf eine demographische Revolution. Überleben und Sterben, Kinderzahl, Verheiratung, Haushalte und Familien, Bildungsstand und Erwerbstätigkeit der Bevölkerung in Deutschland im 20. Jahrhundert im 
Spiegel der Bevölkerungsstatistik. Zeitschrift für Bevölkerungswissenschaft, 24, 3, 229-79.

Silverstein, M., Bengtson, V. L. and Lawton, L. 1997. Intergenerational solidarity and the structure of adult child-parent relationships in American families. American Journal of Sociology, 103, 2, 429-6o.

Sobotka, T. 2008. Does persistent low fertility threaten the future of European populations? In Surkyn, J., van Bavel, J. and Deboosere, P. (eds), Demographic Challenges for the 2 Ist Century. A State of the Art in Demography. VUBPRESS, Brussels, 27-89.

Sobotka, T. and Toulemon, L. 2008. Overview Chapter 4: changing family and partnership behaviour. Demographic Research, 19, 1, 85-138.

Szydlik, M. 1995. Die Enge der Beziehung zwischen erwachsenen Kindern und ihren Eltern - und umgekehrt. Zeitschrift für Soziologie, 24, 2, 75-94.

Szydlik, M. and Künemund, H. 2009. Generationen aus Sicht der Soziologie. In Künemund, H. and Szydlik, M. (eds), Generationen: Multidisziplinäre Perspektiven. VS Verlag, Wiesbaden, Germany, 7-22.

Thornton, A. and Young-DeMarco, L. 2001. Four decades of trends in attitudes toward family issues in the United States: the 196os through the 199os. Journal of Marriage and Family, 63, 4, 1009-37.

Wagner, M., Schütze, Y. and Lang, F. R. 1996. Soziale Beziehungen alter Menschen. In Mayer, K. U. and Baltes, P. B. (eds), Die Berliner Altersstudie: das höhere Alter in interdisziplinärer Perspektive. Akademie Verlag, Berlin, 301-19.

Wenger, G. C., Dykstra, P.A., Melkas, T. and Knipscheer, K. C. P. M. 2007. Social embeddedness and late-life parenthood: community activity, close ties, and support networks. Journal of Family Issues, 28, $11,1419^{-} 5^{6 .}$

Wenger, G. C., Scott, A. and Patterson, N. 2000. How important is parenthood? Childlessness and support in old age in England. Ageing $\mathcal{E}$ Society, 2o, 2, 161-82.

White, L. 2001. Sibling relationships over the life course: a panel analysis. Journal of Marriage and Family, 63, 2, 555-68.

Yang, S. and Rosenblatt, P. C. 2008. Confucian family values and childless couples in South Korea. Journal of Family Issues, 29, 5, 571-91.

Accepted 3 February 2OI5; first published online 9 June 2015

Address for correspondence.

Sebastian Schnettler,

Department of Sociology,

Box 40,

University of Konstanz,

Universitätsstr. 10,

78457 Konstanz, Germany

E-mail: sebastian.schnettler@uni-konstanz.de 